\title{
PERSATUAN DAN KESATUAN
}

\author{
MUHAMMAD RAFI HARTAWAN \\ IIK STRADA INDONESIA
}

NIM 2161B0015

Hartawanrafi10@gmail.com

\begin{abstract}
ABSTRAK
Persatuan dan kesatuan bangsa serta kesatuan wilayah, merupakan suatu kondisi dan cara terbaik untuk mencapai tujuan bersama. Suatu masyarakat yang didorong oleh keharusan pemenuhan kebutuhannya perlu bekerja sama atau bersatu dalam bekerja karena pada dasarnya saling membutuhkan. Masyarakat juga perlu bersatu agar dapat menghimpun kekuatan untuk mencapai suatu tujuan yang tidak dapat dilakukan secara sendiri-sendiri. Disamping itu, pencapaian suatu tujuan masyarakat dapat efektif bila dilakukan dalam satu tatanan atau suatu tata hubungan dalam masyarakat yang berada dalam satu kesatuan.
\end{abstract}

\section{LATAR BELAKANG}

Persatuan dan Kesatuan Bangsa Indonesia diwujudkan dalam semboyan pada lambang Negara Republik Indonesia yaitu "BHINNEKA TUNGGAL IKA" yang keberadaannya berdasarkan pada PP No. 66 Tahun 1951, mengandung arti beraneka tetapi satu. Semboyan tersebut menurut Supomo, menggambarkan gagasan dasar yaitu menghubungkan daerah-daerah dan suku-suku bangsa di seluruh Nusantara menjadi Kesatuan Raya (ST Munadjat D, 1928). Bila dirujuk kepada asalnya yaitu Kitab Sutasoma yang ditulis oleh Empu Tantular abad ke XIV, ternyata semboyan tersebut merupakan seloka yang menekankan tentang pentingnya kerukunan antar umat. 


\section{KASUS/MASALAH}

Keberagaman atau kehidupan dalam lingkungan majemuk bersifat alami dan merupakan sumber kekayaan budaya bangsa. Setiap perwujudan mengandung ciri-ciri tertentu yang membedakannya dari perwujudan yang lain, tidak mungkin satu perwujudan mengandung semua ciri yang ada, karena bila hal itu terjadi maka dia akan menjadi maha sempurna, padahal hanya satu maha sempurna yaitu TUHAN. Tidak mungkin pula bila semua perwujudan sama, karena makanisme tesis-antitesis-sintesis tidak akan terjadi, dalam arti tidak akan ada perkembangan atau kemajuan. Didunia ini yang "tetap" adalah perubahan terus menerus mengikuti hukum evolusi (Charles Darwin) yang ditegaskan oleh Herakletos, bahwa satu-satunya realitas ialah perubahan. Atas dasar pemahaman tersebut, perbedaan-perbedaan yang ada dalam kehidupan masyarakat Indonesia sebenarnya untuk memenuhi kepentingan bersama agar dapat hidup sejahtera.

Dalam kehidupan masyarakat yang serba majemuk, berbangsa dan bernegara, berbagai perbedaan yang ada seperti dalam suku, agama, ras atau antar golongan, merupakan realita yang harus didayagunakan untuk memajukan negara dan bangsa Indonesia, menuju cita-cita Nasional kita adalah masyarakat Adil dan Makmur berdasarkan Pancasila dan UUD 1945 dalam Negara Kesatuan Republik Indonesia. Bangsa kita tidak hanya memiliki satu agama saja, tetapi beraneka ragam agama sekaligus budaya maupun adat. 


\section{PEMBAHASAN}

Sebagai negara yang memiliki keanekaragaman itu, kita harus bersatu dan saling toleransi. Tidak peduli apa agama yang dianut maupun kepercayaan apa yang dipercayai, kita tetap berbangsa satu yaitu bangsa Indonesia. Walaupun mereka sedang melaksanakan kegiatan ibadah, janganlah diganggu.

Kita harus menghormati kegiatan ibadah yang berbeda agama dan mencegah adanya perpecahan antar umat beragama. Coba bayangkan yang akan terjadi jika perpecahan antar umat beragamaterus berlanjut dan mengakibatkan perang antar sesama penduduk. Akan hancur dan rusak negara ini nantinya serta musuh-musuh dari negara lain juga senantiasa dengan mudah menghancurkan negeri tercinta ini.

Menurut Kamus Besar Bahasa Indonesia (KBBI) edisi keempat, persatuan adalah gabungan (ikatan, kumpulan dan sebagainya) beberapa bagian yang sudah bersatu, perserikatan, serikat.

Sementara pengertian kesatuan berarti perihal satu, keesaan, sifat tunggal, satuan. Itu adalah pengertian secara terminologis. Untuk pengertian secara lebih luasnya adalah sebagai berikut. Persatuan berasal dari kata 'satu' yang berarti utuh dan tidak terpecah-belah. Arti lebih luasnya, yaitu berkumpulnya macam-macam corak dari berbagai kalangan, ras, budaya, dan adat istiadat dalam masyarakat yang bersatu dengan serasi.

Sedangkan Kesatuan merupakan hasil dari persatuan yang telah menjadi utuh. Hal ini dilakukan untuk terhindar dari disintegrasi. Selain itu kita juga harus mengetahui terlebih dahulu perbedaan antara persatuan dan kesatuan ini. Walau istilah persatuan dan kesatuan saling bersinggungan, keduanya memiliki suatu perbedaan. Persatuan merupakan suatu proses dalam keadaan membentuk masyarakat untuk bersatu, sementara kesatuan merupakan wujud bersatunya masyarakat yang sudah terbentuk. Selama ini, bangsa Indonesia menerapkan atau menimplementasikan persatuan dan kesatuan dalam 3 aspek, yaitu : 
- Menjalin rasa kepercayaan satu sama lain antara rakyat Indonesia dan saling melengkapi satu sama lain guna Langkah awal untuk menjalin persatuan dan kesatuan ini

- Menghargai satu sama lain tanpa membedakan ras, suku, dan golongan guna terciptanya lingkungan yang kondusif dan aman

- Menjalin rasa kekeluargaan dan semangat jiwa korsa agar persatuan dan kesatuan yang sudah ada tetap terjaga

\section{Prinsip kesatuan dan persatuan yaitu :}

1. Bhinneka Tunggal Ika

Salah satu prinsip persatuan dan kesatuan adalah prinsip Bhinneka Tunggal Ika yang memaknai kita agar mengakui bahwa bangsa Indonesia memiliki keragaman suku, bahasa,agama,dan adat kebiasaan. Prinsip pertama persatuan dan kesatuan bangsa adalah semboyan Bhinneka Tunggal Ika yang tercantum dalam Undang-undang Republik Indonesia nomor 24 tahun 2009 tentang bendera, bahasa, dan lambang negara, serta lagu kebangsaan.

"Yang dimaksud dengan "semboyan Bhinneka Tunggal Ika" adalah pepatah lama yang pernah dipakai oleh pujangga ternama Mpu Tantular. Kata bhinneka merupakan gabungan dua kata: bhinna dan ika diartikan berbeda-beda tetapi tetap satu dan kata tunggal ika diartikan bahwa di antara pusparagam bangsa Indonesia adalah satu kesatuan. Semboyan ini digunakan mengggambarkan persatuan dan kesatuan bangsa dan Negara Kesatuan Republik Indonesia." Prinsip Bhinneka Tunggal Ika mempersatukan masyarakat Indonesia yang berbeda-beda menjadi tetap satu. Prinsip ini menjauhkan masyarakat Indonesia dari diskriminasi sehingga persatuan dan kesatuan dapat tercapai.

2. Nasionalisme 
Indonesia Prinsip nasionalisme Indonesia mengajari kita untuk mencintai bangsa, membangun tali kekeluargaan antarwarga, menumbuhkan rasa rela berkorban bagi negara. Prinsip nasionalisme juga membuat masyarakat memiliki cita-cita dan tujuan yang sama bagi kemajuan bangsa.

3. Kebebasan yang Bertanggung Jawab

Prinsip kebebasan yang bertanggung jawab adalah prinsip yang memberikan kebebasan individu untuk berperilaku dan berpendapat namun tetap mempertimbangkan kepentingan bersama. Prinsip kebebasan yang bertanggung jawab mendorong demokrasi namun tetap mengindahkan hak asasi manusia juga kepentingan bangsa.

4. Wawasan Nusantara

Wawasan nusantara adalah pedoman dan cara pandang bangsa Indonesia yang dilandaskan oleh Pancasila dan Undang-Undang Republik Indonesia. Wawasan nusantara mempersatukan cara pandang bangsa, pedoman, dan aturan dalam meraih tujuan bangsa dan mempertahankan persatuan serta kesatuan.

5. Persatuan Pembangunan

Prinsip terakhir dalam persatuan dan kesatuan bangsa Indonesia adalah persatuan pembangunan demi mewujudkan cita-cita reformasi. prinsip ini memersatukan masyarakat Indonesia yang beragam dalam satu tujuan yaitu mewujudkan cita-cita reformasi bangsa. Cita-cita reformasi memiliki tujuan luhur yaitu mewujudkan bangsa Indonesia yang lebih baik, maju, sejahtera, dengan kebebasan demokrasi dan pemerintah yang transparan serta pro terhadap rakyat.

\section{KESIMPULAN}

Untuk itulah, mari kita mengingat kembali sejarah negara Indonesia yang telah lama terukir dan melihat kembali ke masa lalu. Kira-kira pada saat masa penjajahan yang terjadi sekitar puluhan tahun yang lalu. Pada awalnya, mereka 
hanya berjuang dengan sistem kedaerahan. Maksudnya yaitu gerakan perjuangan untuk membela negara dalam usaha mendapatkan kemerdekaan pada saat itu masih belum bersatu atau bisa dibilang masih terpecah belah.

Karena pada masa itu, sistem pemerintahan yang digunakan masih bersifat kerajaan dan juga hasutan serta bisikan dari bangsa penjajah dengan mudah menciptakan perang antar saudara di Indonesia. Hal itulah yang sering menciptakan kekalahan pada saat perlawanan.

Walaupun strategi yang dibuat jauh hari sebelum perjuangan sudah disiapkan matang-matang, akan percuma juga kalau gagal karena lemahnya persatuan dan kerja sama dalam mencapai kemenangan dalam perjuangan itu. 
https://www.kompasiana.com/adinda24370/615f5e050101904e120 d0a26/persatuan-dan-kesatuan

https://www.kompasiana.com/mohammadattargibran4011/615f3a3 $\underline{\text { f24da9253c7754464/tantangan-persatuan-dan-kesatuan-bangsa }}$ https://www.kompas.com/skola/read/2021/04/14/125118469/prins ip-prinsip-persatuan-dan-kesatuan-bangsa-indonesia 
